\title{
Bioactive potential of bacterial endosymbionts isolated from Lamellodysidea herbacea, marine sponge from the coast of South Andaman, India, against human bacterial pathogens
}

\author{
Sneha Sawhney, Jayant Kumar Mishra* \\ Department of Ocean Studies and Marine Biology, Pondicherry University, Port Blair, Andaman \& Nicobar Islands, India.
}

\begin{tabular}{|c|c|}
\hline ARTICLE INFO & ABSTRACT \\
\hline $\begin{array}{l}\text { Received on: } 12 / 12 / 2018 \\
\text { Accepted on: 09/02/2019 } \\
\text { Available online: } 30 / 03 / 2019\end{array}$ & $\begin{array}{l}\text { Sponge diversity along the coasts of Andaman and Nicobar Islands comprises about } 126 \text { species and sponges are known } \\
\text { to act as a host to endosymbionts, which is found to possess novel antimicrobial metabolites. In the present study, } \\
\text { screening and characterization of antibiotic producing endosymbiotic bacteria from the marine sponge Lamellodysidea } \\
\text { herbacea were investigated. Eight isolated bacterial strains from the sponge were screened for bioactivity against }\end{array}$ \\
\hline $\begin{array}{l}\text { Key words: } \\
\text { Andaman Sea, bioactive } \\
\text { metabolites, endosymbiotic } \\
\text { bacteria, L. herbacea. }\end{array}$ & $\begin{array}{l}\text { human pathogens Escherichia coli (MTCC 443), Bacillus cereus (MTCC 430), Bacillus subtilis (MTCC 121), Listeria } \\
\text { monocytogenes (MTCC 839), Staphylococcus aureus (MTCC 3160) and Salmonella enterica typhimurium (MTCC } \\
\text { 1252) and only two strains CAB1 and CAB38 exhibited activity. Ethyl acetate extracted metabolites of strain CAB1 } \\
\text { showed significant activity against four pathogens B. cereus, B. subtilis, S. aureus and S. entrica typhimurium and } \\
\text { CAB38 against three pathogens B. subtilis, E. coli and S. entrica typhimurium. The } 16 \mathrm{~S} \text { rRNA gene sequence of these } \\
\text { two strains showed } 99 \% \text { sequence similarity with known sequences in the GenBank and their phylogenetic analysis } \\
\text { confirmed strain CAB1 as Bacillus amyloliquefaciens (MK135790) and CAB38 as Alcaligenes faecalis (MK135791). } \\
\text { The study demonstrated that metabolites from sponge associated bacterial endosymbionts can be a major source of } \\
\text { unique compounds with potential bioactivity. }\end{array}$ \\
\hline
\end{tabular}

\section{INTRODUCTION}

The quest for novel biomolecules with potential therapeutic value always remains a challenge as the resistance by pathogenic microorganisms is increasing day by day. In this process, infectious disease-causing microbes have become a fatal threat to human being worldwide (Handayani et al., 2015; Mehbub et al., 2014). Thus, research studies have been carried out to find new bioactive molecules from marine natural resources. The marine environment in this context has made a significant contribution as the marine organisms possess structurally unique molecules with significant biomedical potentiality (Bhatnagar and Kim, 2010; Thomas et al., 2010). The studies on the natural

"Corresponding Author

Jayant Kumar Mishra, Professor, Department of Ocean Studies and Marine Biology, Pondicherry University, Port Blair, Andaman \& Nicobar Islands, India.E-mail: jkmishra.omb@pondiuni.edu.in resources from the sea suggest that there are abundant biologically active compounds originating from marine microorganisms and particularly from sponge-associated microorganisms with potential effect against human pathogens (Bhatnagar and Kim, 2010; Kobayashi and Ishibashi, 1993; Mehbub et al., 2014; Ridley et al., 2005). With this perspective, marine sponges have been in focus in recent years due to their abundant source of biologically active secondary metabolites and their association with a wide range of microorganisms (Kumar et al., 2012; Thacker and Freeman, 2012).

The symbiotic microorganisms of sponge are highly diversified and include archaea, bacteria, cyanobacteria, green algae, red algae, diatoms, dinoflagellates and fungi and constitute even up to $40 \%-60 \%$ of the sponge biomass (Hentschel et al., 2001; Lee et al., 2001; Maldonado et al., 2005; Taylor et al., 2007; Zeng et al., 2013). These microbial associates remain in high densities with the sponge tissue and have a significant influence on the life cycle of its host sponge (Taylor et al., 2007; Webster and Taylor, 2012). Consequently, these microorganisms 
have become the basis for developing new drugs with structurally unique compounds that have direct application in curing diseases such as cancer, HIV, tuberculosis, malaria, microbial infections like bacterial, fungal, viral, etc. (Mehbub et al., 2014). In addition, symbiotic microorganisms also found to serve as a source of nutrition by transferring metabolite products, contribute to the structural rigidity and also produce bioactive metabolites for the protection of their host sponge (Belarbi et al., 2003; Hildebrand et al., 2004; Ridley et al., 2005; Schmidt et al., 2000). Reports suggest that a large number of bioactive compounds are contributed by demosponges (Dhinakaran et al., 2014; Hooper and Soest, 2002).

The Andaman Sea surrounding A \& N Islands, India, is bestowed with rich marine living resources with a total of 6,748 species, among which 126 species are sponges (Pereira et al., 2016). One such species Lamellodysidea herbacea (Keller, 1889) is a tropical shallow-water sponge found commonly throughout the Indo-Pacific region (Hentschel et al., 2001; Newman and Hill, 2006) and also being reported earlier from North Bay, Chidiyatapu, Pongibalu, Ritchie's Archipelago, Havelock and Nicobar Islands in the Andaman sea (Kiruba et al., 2014; Immanuel et al., 2015). During the present investigation, $L$. herbacea was collected from the intertidal zone at Carbyn's Cove for the isolation of endosymbiotic bacteria from its internal part and screen them for bioactive potential strains against human pathogens. It was interesting to note that the intertidal sponge $L$. herbacea offered a potential source of biologically active compounds, which was isolated from their associated bacteria.

Though there are more than 126 sponge species available in these Islands, still there is a huge gap and limited studies have been carried out on the bioactive potential of these organisms. Some investigations carried out earlier on the sponges from the Andaman Sea, India, mainly focused on the isolation of sponge-associated bacteria and activity of their crude extracts against various pathogens and cancerous cells (Adhavan and Mishra, 2012; Devi and Revathi, 2015; Krishnan et al., 2014; Muthiyan et al., 2017). Also, a recent study by the author reported that the crude extract of Bacillus velezensis CHB2 isolated from sponge Biemna fortis exhibited inhibiting effect against five pathogens B. cereus, B. subtilis, E. coli, L. monocytogenes and S. aureus (Sawhney et al., 2018). The present study was aimed at isolating the bacterial endosymbionts from the sponge $L$. herbacea and identifies bioactive potential strains against human pathogens.

\section{MATERIALS AND METHODS}

\section{Sponge collection and identification}

Marine sponge Lamellodysidea herbacea Keller (1889) (Fig. 1), was collected from the intertidal region at Carbyn's Cove (Lat. $11^{\circ} 38^{\prime} 41.36^{\prime \prime} \mathrm{N}$; Long. 92 $44^{\prime} 57.46^{\prime \prime} \mathrm{E}$ ) along the coast of South Andaman. Samples were transferred to sterile polythene bags and immediately carried to the laboratory for isolation of endosymbiotic bacteria. A fragment of sponge specimen was also preserved in $70 \%$ ethanol for taxonomic identification.

\section{Isolation of the endosymbiotic bacteria and their screening for} bioactivity

Sponge sample was washed with sterilized filtered seawater to remove all the debris and then the sponge was surface sterilized using 70\% ethanol and immersed in sterile seawater immediately and aspirated. One gram of sponge tissue from the center was cut using a sterile scalpel and immediately transferred to $99 \mathrm{ml}$ sponge dissociation medium $(2.7 \mathrm{NaCl}, 0.008 \mathrm{KCl}$ and 0.01 $\mathrm{Na}_{2} \mathrm{SO}_{4}$ ) and soaked for 20 minutes. Then, the tissues and diluents were macerated in a sterile mortar and pestle. The homogenized tissue was serially diluted up to $10^{-5}$ using $50 \%$ seawater and plated on Zobell Marine Agar media, 2216 (ZMA, HiMedia). The plates were then incubated at room temperature for 7 days for the development of bacterial colonies. Following this, colonies were streaked on ZMA slants to obtain pure culture and stored at $4^{\circ} \mathrm{C}$ for further studies (Anand et al., 2006). In this, a total of 10 bacterial strains were isolated from $L$. herbacea and only eight of them could be sub-cultured in the laboratory conditions. These eight sub-cultured strains were tested for antibacterial activity against six pathogens B. cereus (MTCC 430), B. subtilis (MTCC 121), E. coli (MTCC 443), L. monocytogenes (MTCC839), S. aureus (MTCC 3160) and S. enterica typhimurium (MTCC 1252) initially by the cross streak method (Lertcanawanichakul and Sawangnop, 2008), followed by the agar plug method (Radhakrishnan et al., 2016; Silambarasan et al., 2012) and then by the agar disc diffusion method (Kirby-Bauer method). The most potential strains were identified using biochemical tests and 16S rRNA sequencing and further metabolites from these active strains were extracted and subjected to bioassay against human pathogens to assess its bioactive potential.

\section{Biochemical tests}

Biochemical and enzymatic tests were also carried out for the identification of the strains. The various tests included are indole, methyl red, Voges-Proskauer, citrate utilization, glucose, sucrose, adonitol, arabinose, sorbitol, catalase, protease, amylase and cellulase.

\section{PCR amplification, sequencing and phylogenetic analysis of 16S rRNA gene}

The genomic DNA of the bacterial strains CAB1 and CAB3 8 was confirmed by $0.8 \%$ (w/v) agarose gel electrophoresis. The strains $\mathrm{CAB} 1$ and $\mathrm{CAB} 38$ were identified to the species level by PCR amplification of the 16S rRNA gene, followed by sequencing. The $16 \mathrm{~S}$ rRNA gene was amplified using universal primers 27F (5'-AGAGTTTGATCCTGGCTCAG-3') and 1492R (5'-GGTTACCTTGTTACGACTT-3') (Penesyan et al., 2011) to generate a PCR product. The PCR products obtained were then purified and sequenced from Eurofins Pvt. Ltd., Bangalore. The partial sequence of $16 \mathrm{~S}$ rRNA obtained was then subjected to Basic Local Alignment Search (BLAST) analysis and compared with sequences available in the GenBank nucleotide database. Phylogenetic analysis was performed by aligning different $16 \mathrm{~S}$ rRNA partial sequences retrieved from the BLAST algorithm (http://www.ncbi.nlm.nih.gov), using the CLUSTAL W program with standard parameters. Phylogenetic and molecular evolutionary 

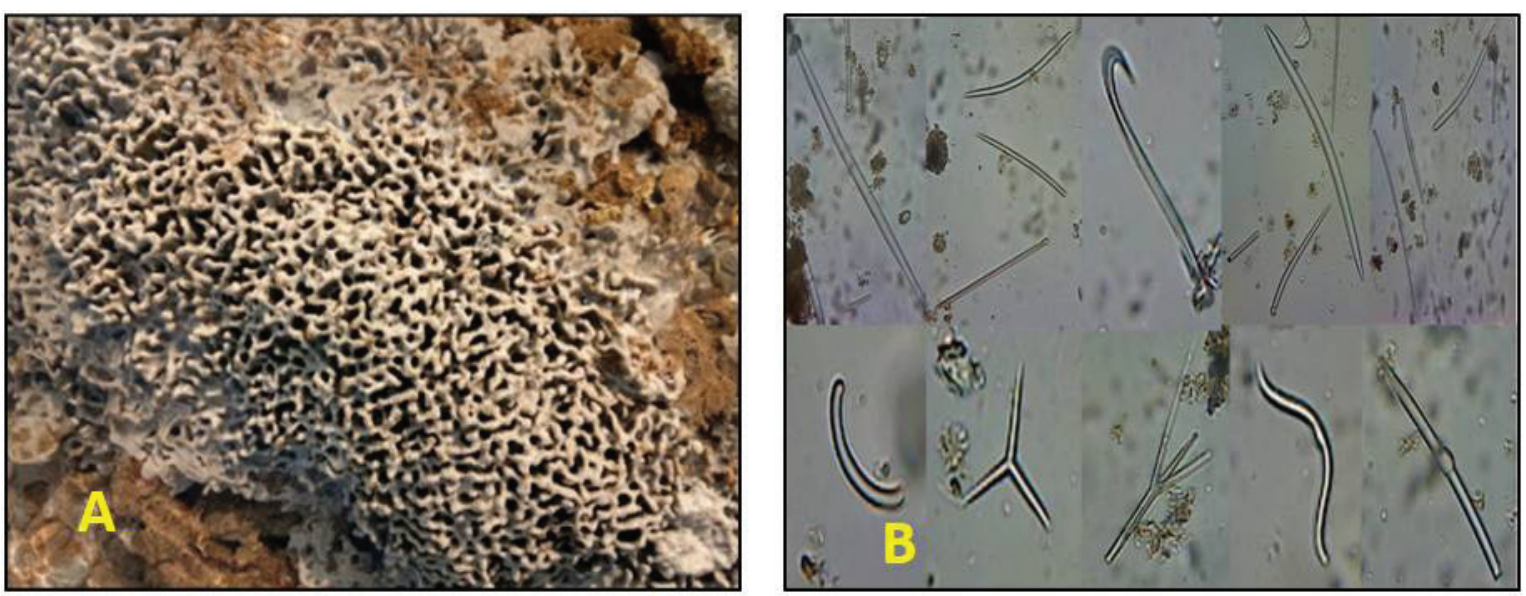

Figure 1. (A) Lamellodysidea herbacea (Keller, 1889); (B) Spicules of L. herbacea under the microscope.

analyses were conducted using MEGA version 6 (Tamura et al., 2013). A rooted phylogram was obtained by the maximum likelihood method and an interior branch test was done $(1,000$ bootstrap replications) to check the tree topology for robustness. The strain CAB1 (GenBank accession number MK135790) was identified as Bacillus amyloliquefaciens and CAB38 (GenBank accession number MK135791) as Alcaligenes faecalis.

\section{Extraction of secondary metabolites from active bacterial strains}

For the solvent extraction of metabolites, both the potential strains B. amyloliquefaciens CAB1 (MK135790) and A. faecalis CAB38 (MK135791) were inoculated into $50 \mathrm{ml}$ of Zobell Marine Broth (ZMB, Himedia) separately for seed culture by keeping in a shaker incubator (REMI CIS-24 Plus) for 18 hours at $30^{\circ} \mathrm{C}$ at $150 \mathrm{rpm}$. These inoculums were then transferred to 500 $\mathrm{ml} \mathrm{ZMB}$ and incubated in shaker incubator for 5 days at $28^{\circ} \mathrm{C}$ at $150 \mathrm{rpm}$ (Gopi et al., 2012). The bacterial cells were separated from the fermentation medium by centrifugation (MPW-350R High speed, brushless centrifuge) at $10,000 \mathrm{rpm}$ at $4^{\circ} \mathrm{C}$ for 15 minutes.

For the extraction of active metabolites from the bacterial supernatant, ethyl acetate was used. Solvent and the cellfree extract were taken in 2:1 ratio in a separating flask and shaken vigorously for 30 minutes and kept in a burette stand for 1 hour. The organic phase containing compounds was separated from the supernatant and concentrated using rotary evaporator (STRIKE 202, Kentron) to remove the solvent under pressure at $40^{\circ} \mathrm{C}$ (Zheng et al., 2005). The obtained crude extract was dissolved in methanol $(100 \mathrm{mg} / \mathrm{ml})$ and stored in $4^{\circ} \mathrm{C}$ for further studies on antibacterial activities.

\section{Antibacterial activity of extracted metabolite from endosymbiotic bacteria}

Antibacterial assay was conducted using the agar disc diffusion method (Kirby Bauer method). The plates with Muller Hinton Agar (MHA, HiMedia) were spread with six pathogens, B. cereus (MTCC 430), E. coli (MTCC 443), B. subtilis (MTCC 121), L. monocytogenes (MTCC 839), S. aureus (MTCC 3160) and S. enterica typhimurium (MTCC 1252) separately using sterile cotton swabs. A volume of $100 \mu \mathrm{l}$ of the crude extract was added to the $10 \mathrm{~mm}$ sterile disc (Whatman) and allowed to dry at room temperature for 1 hour and then placed on the surface of the MHA plates inoculated with test pathogens. For negative control, $100 \mu \mathrm{l}$ of methanol was added on the sterile disc, while the positive control used was a standard antibiotic disc (Gentamicin G30, HiMedia). The zone of inhibition ( $\mathrm{mm}$ ) was measured from the edge of the disc after incubating the plates at $37^{\circ} \mathrm{C}$ for 24 hours.

\section{In-vitro heat and salt tolerance of potential strains}

The temperature tolerance of potential bacterial strains $\mathrm{CAB} 1$ and $\mathrm{CAB} 38$ was assessed by following the modified method of Akond et al. (2016); Verma et al. (2018). The temperature tolerance was assessed by inoculation of freshly grown potential bacterial strains $\mathrm{CAB} 1$ and $\mathrm{CAB} 38$ in nutrient broth medium (HiMedia) separately at different sets of incubation temperatures of $40^{\circ} \mathrm{C}, 45^{\circ} \mathrm{C}, 50^{\circ} \mathrm{C}, 55^{\circ} \mathrm{C}$ and $60^{\circ} \mathrm{C}$ at $120 \mathrm{rpm}$ in a Shaker Incubator (REMI CIS-24 Plus) for 24 hours. Then, the incubated cultures were spot inoculated on nutrient agar plates incubated at room temperature for 24 hours and their bacterial colony growth was examined.

For the $\mathrm{NaCl}$ tolerance, freshly grown colonies of potential bacterial strains were streaked on nutrient agar medium supplemented with concentrations of $8 \%$ and $10 \% \mathrm{NaCl}$, separately for 24 hours at $37^{\circ} \mathrm{C}$. The nutrient agar without $\mathrm{NaCl}$ was used as control (Mendpara et al., 2013).

\section{RESULTS}

\section{Isolation of bacteria from the sponge and their screening}

In the present study, out of 10 isolated strains, only eight bacterial strains CAB1, CAB2, CAB3, CAB4, CAB5, $\mathrm{CAB} 31, \mathrm{CAB} 32$ and $\mathrm{CAB} 38$ could be sub-cultured and these strains comprise four Gram-negative and four Gram-positive bacteria. The biochemical tests such as indole, Voges-Proskauer, citrate utilization and carbohydrate utilization of glucose, sucrose, adonitol, arabinose and sorbitol along with enzymatic tests for catalase, protease, amylase and cellulase were conducted (Table 1). 
Table 1. Biochemical and enzymatic tests of isolated bacterial strains CAB1, CAB2, CAB3, CAB4, CAB5, CAB31, CAB32, and CAB38.

\begin{tabular}{|c|c|c|c|c|c|c|c|c|c|c|c|c|c|c|}
\hline Isolates & Gram's +/- & Ind & MR & VP & $\mathrm{CU}$ & Glu & Suc & Ado & Ara & Sor & Cat & Pro & Amy & Cel \\
\hline $\mathrm{CAB} 1$ & $\mathrm{G}+\mathrm{ve}$ Rods & - & - & + & - & + & + & - & - & - & + & + & + & + \\
\hline $\mathrm{CAB} 2$ & $\mathrm{G}$-ve, Rods & - & + & - & + & - & - & - & - & - & + & + & - & + \\
\hline CAB3 & $\mathrm{G}$-ve, Rods & - & + & - & - & + & + & - & + & - & + & + & + & - \\
\hline CAB4 & $\mathrm{G}+\mathrm{ve}$ Cocci & + & - & - & - & + & + & - & - & - & + & + & + & - \\
\hline CAB5 & $\mathrm{G}+$ ve Cocci & + & - & - & - & + & + & - & - & - & - & + & - & - \\
\hline CAB31 & $\mathrm{G}$ - ve Rods & - & - & - & - & + & + & - & + & - & - & + & + & - \\
\hline CAB32 & $\mathrm{G}+\mathrm{ve}$ Rods & - & - & - & - & + & + & - & - & - & + & + & - & - \\
\hline CAB38 & $\mathrm{G}$-ve Rods & - & - & - & + & - & - & - & - & - & + & + & + & + \\
\hline
\end{tabular}

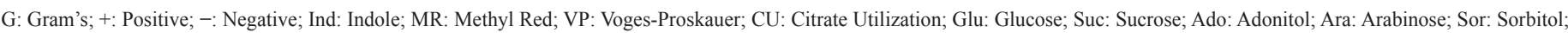
Cat: Catalase; Pro: Protease; Amy: Amylase; Cel: Cellulase.

The initial screening of eight isolated strains for their antibacterial activity by both the cross streaking and agar plug method showed that only two strains CAB1 and CAB38 were active.

\section{Molecular identification}

Species-level identification was determined by $99 \%$ sequence similarity of $16 \mathrm{~S}$ rRNA with the sequence available on the GenBank. Sequence alignment and comparison was performed using multiple sequence alignment program CLUSTAL W using Mega version 6.0 software. Phylogenetic tree was constructed using the Maximum likelihood method for both the strains based on the Hasegawa-Kishino-Yano model as the best fitting model with 1,000 bootstrap replications. Bar 0.02 substitutions per nucleotide position were adopted. The outgroups used were Bacillus cereus (MH769499) in the case of strain CAB1 and Paenalcaligenes suwonensis (NR133804) in the case of strain CAB38. The 16S rRNA sequences of the isolates were deposited in GenBank database under respective accession number MK135790 and MK135791 for CAB1 and CAB38. Based on the nucleotide homology and phylogenetic analysis, both $\mathrm{CAB} 1$ and CAB38 were identified as B. amyloliquefaciens and A. faecalis, respectively (Fig. 2).

The gel electrophoresis of PCR product both of the active stains CAB1 B. amyloliquefaciens and CAB38 A. faecalis exhibited a band of $1.5 \mathrm{~kb}$ on $0.8 \%(\mathrm{w} / \mathrm{v})$ agarose gel in $1 \times \mathrm{TAE}$ buffer when compared to 100 bp DNA ladder (HiMedia) (Fig. 3).

In the present assay, only two isolated strains out of 10 isolates, i.e., $20 \%$ of the strains were found to be antibiotic producers against human pathogens. The antibiotic-producing activity varied from strain to strain as found in the in-vitro assay of ethyl acetate extracts of both the active strains against human pathogens (Fig. 4). The extract of B. amyloliquefaciens CAB1 showed activity against four pathogens B. cereus, B. subtilis, $S$. aureus and $S$. entrica typhimurium with prominent zone of inhibition as 18, 12, 20 and $12 \mathrm{~mm}$, respectively (Fig. 4A), whereas the extract of $A$. faecalis CAB38 showed activity against three pathogens $B$. subtilis, E. coli and $S$. entrica typhimurium with the inhibition zone of 15, 16 and $12 \mathrm{~mm}$, respectively (Fig. 4B). But both the strains commonly exhibited activity against $B$. subtilis and $S$. entrica typhimurium and there was no activity against $L$. monocytogens exhibited by any of the strains.

The highest activity was noted by the strain $B$. amyloliquefaciens $\mathrm{CAB} 1$ against $S$. aureus with very a prominent inhibition zone of $20 \mathrm{~mm}$, whereas in case of A. faecalis CAB38, the highest zone of inhibition of $16 \mathrm{~mm}$ was noted against $E$. coli (Table 2).

The results suggest that the crude extract of two endosymbionts had an antagonistic effect on five pathogens and did not have any effect on $L$. monocytogens, which is a Gramnegative bacteria. The temperature tolerance tests for both the strains suggest that both of the strains have thermal stability, which can withstand and could be revived even after incubation at $60^{\circ} \mathrm{C}$ for 24 hours in the case of B. amyloliquefaciens CAB1, whereas A. faecalis $\mathrm{CAB} 38$ can be retrieved at $40^{\circ} \mathrm{C}$. The salt tolerance was observed for $B$. amyloliquefaciens $\mathrm{CAB} 1$ at the upper limit of $8 \% \mathrm{NaCl}$, whereas $A$. faecalis $\mathrm{CAB} 38$, it was both at $8 \%$ and $10 \%$ of $\mathrm{NaCl}$.

\section{DISCUSSION}

Due to the emergence of multi-resistant pathogenic micro-organisms, attempts to discover new antibiotic-producing strains have increased (Anand et al., 2006) and this has accelerated the search for new marine natural products ( $\mathrm{Hu}$ et al., 2011). Among all the marine organisms investigated, sponges have been the richest sources of marine natural products (Mehbub et al., 2014). These holobionts serve as the host for many microorganisms (Webster and Taylor, 2012), which contribute to host health, ecology and evolution (Pawlik et al., 2002; Taylor et al., 2007). It is also been reported that in the sponge-associated microbiome, about $90 \%$ of the antimicrobial compounds found to be produced by bacteria, $10 \%$ by fungi and Bacillus sp. contribute about 9\% (Indraningrat et al., 2016). In the present study, eight symbiotic strains from sponge $L$. herbacea have been isolated, of which $20 \%$ of the isolated strains exhibited antibacterial activity against human pathogens. Out of these eight strains, Grampositive and Gram-negative strains were in equal proportion and six were rods and two were cocci type strains. Although other six strains did not have any effect on the assayed pathogens in this investigation, they may have some beneficial role in the lifecycle of the host sponge. Also, both the biochemical and enzymatic test showed specific characteristics of the strains. As many Grampositive bacteria are endospore producers at adverse conditions like the marine environment, it might be helpful to survive in the marine environment (Hentschel et al., 2001). Also, potential marine microorganisms are used as a source of industrially important enzymes for extracellular enzymatic activities like amylase, cellulase and protease. These two isolated microbial strains also possess characteristic features like thermostability and 


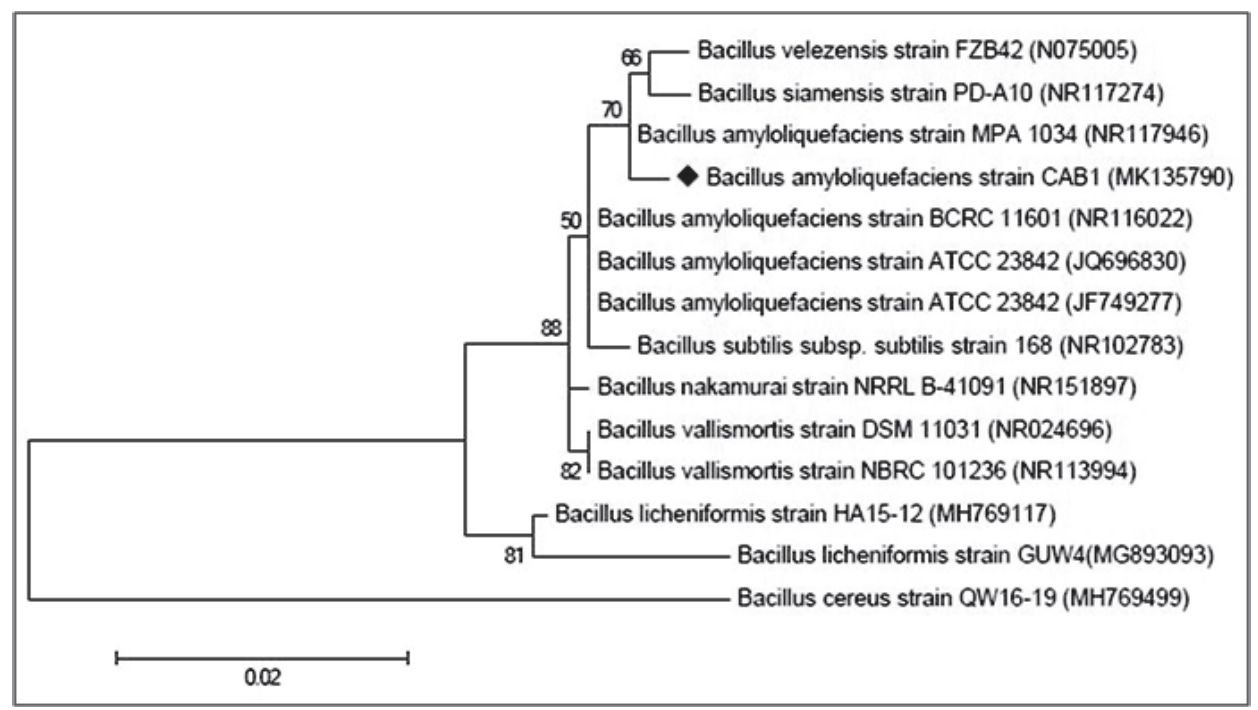

A. Bacillus amyloliquefaciens $\mathrm{CAB} 1$

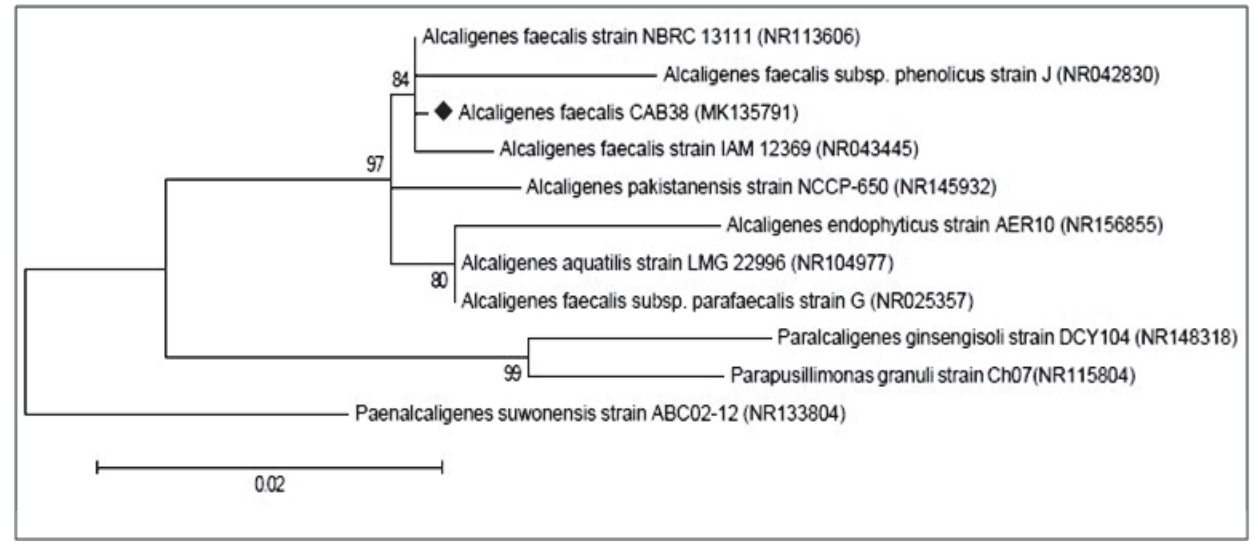

\section{B. Alcaligenes faecalis $\mathrm{CAB} 38$}

Figure 2. Phylogenetic tree for isolates (A) B. amyloliquefaciens CAB1 and (B) CAB38 A. faecalis constructed using the Maximum Likelihood method.

salinity tolerance. It has also been documented that only $1 \%$ of the microbes are being cultured with present techniques, which shows bioactivity, but other non-culturable species, which are also available in the sponge tissue, may also be having significant bioactive potential specific to its host sponge (Hentschel et al., 2001; Proksch et al., 2002).

Although both the strains were found to possess active molecules, the extracts obtained from $B$. amyloliquefaciens were more active against four pathogens with the highest zone of inhibition in comparison to the extracts of $A$. faecalis, which showed activity against three pathogens. Previously from many other sources, different strains of $B$. amyloliquefaciens have been isolated such as sediments, sponges, tannery soil, etc. and $B$. amyloliquefaciens MB-101 isolated from sponge Callyspongia diffusa showed biosurfactant properties (Dhasayan et al., 2015). In another study by Flemer et al. (2011), it was found that three strains of B. amyloliquefaciens $\mathrm{W} 15 \mathrm{C} 18 \mathrm{a}, \mathrm{W} 15 \mathrm{C} 2$ and W15M1A from sponge Leucosolenia sp. had antibacterial and antifungal

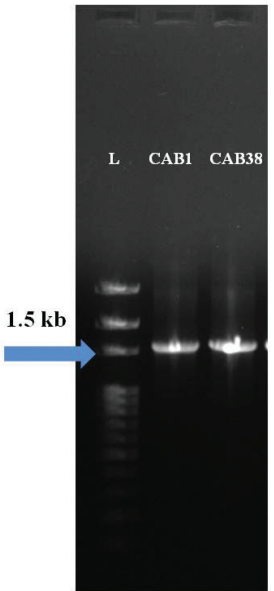

Figure 3. Agarose Gel Electrophoresis showing $1.5 \mathrm{~kb}$ DNA fragment of $16 \mathrm{~S}$ rRNA of B. amyloliquefaciens $\mathrm{CAB} 1$ and $A$. faecalis CAB38. "L" denotes 100 bp DNA Ladder. 


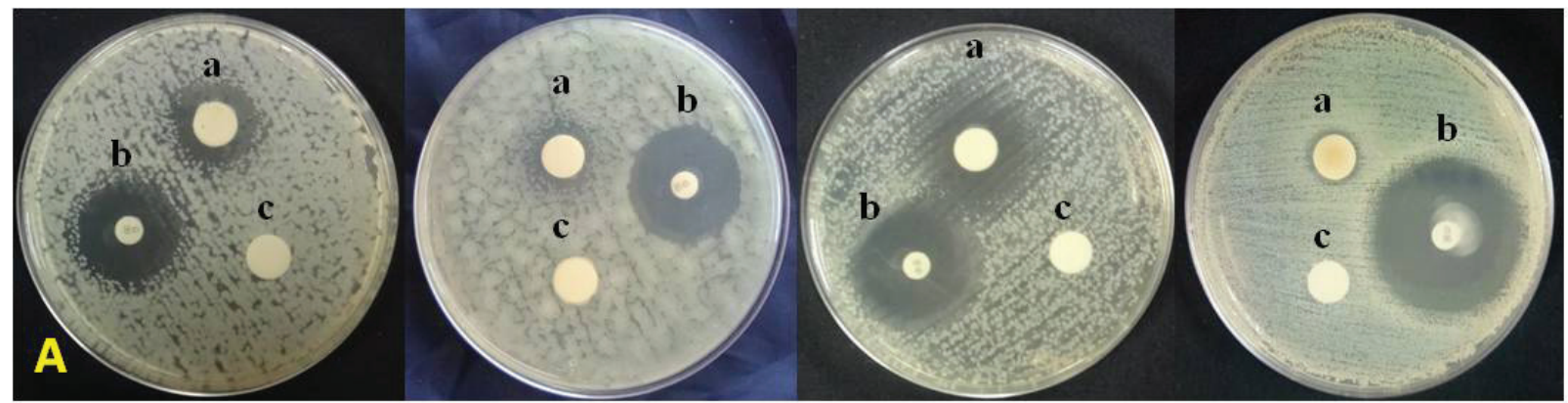

B. cereus

B. subtilis

S. aureus

S. entrica typhimurium

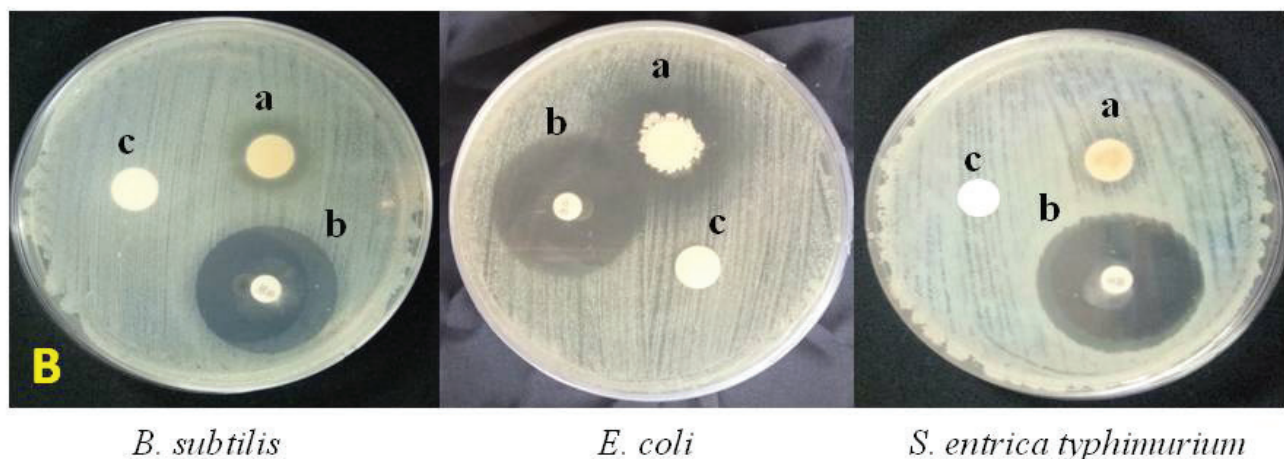

Figure 4. (A and B) Effect of crude extract of B. amyloliquefaciens and A. faecalis against different human pathogens (a: Disc containing crude extract; b: Standard antibiotic disc; and c: Disc containing Methanol).

Table 2. Zone of Inhibition by the crude extracts of B. amyloliquefaciens and A. facealis against human pathogens.

\begin{tabular}{ccccccc}
\hline \multirow{2}{*}{ S. No. } & \multirow{2}{*}{ Isolated Bacteria } & \multicolumn{5}{c}{ Zone of inhibition $(\mathrm{mm})$ against pathogens } \\
\cline { 3 - 6 } & & B. cereus & B. subtilis & E. coli & S. aureus & S. entrica typhimurium \\
\hline 1. & B. amyloliquefaciens & 18 & 12 & - & 20 & 12 \\
2. & A. facealis & - & 15 & 16 & - & 12 \\
\hline
\end{tabular}

$-:$ absent.

activity. However, the present result suggested that crude extracts from $B$. amyloliquefaciens have a significant antagonistic effect on four pathogens $B$. cereus, B. subtilis, S. aureus and S. entrica typhimurium and extracts from $A$. faecalis against three pathogens B. subtilis, E. coli and S. entrica typhimurium.

The earlier reports suggested that the compound L,LDiketopiperazines extracted from A. faecalis A72 (GenBank No. DQ180141) from sponge Stelletta tenuis showed significant activity against $B$. subtilis and moderate activity against Aspergillus niger, Paecilomyces variotii and Candida albicans (Li et al., 2007; 2008). The present study also confirms that the extracts obtained from strain A. faecalis $\mathrm{CAB} 38$ contain some unique compounds, which have an inhibitory effect on bacterial pathogens. Similarly, one strain of A. faecalis isolated from Moroccan tannery waste had a broad spectrum of antibacterial activity against both the Gram-positive and negative bacteria, i.e., M. smegmatis, E. coli, P. aeruginosa, B. subtilis and S. aureus (Zahir et al., 2013). A similar trend was observed in this study, where the compound/s in the crude extracts of $A$. faecalis exhibited activity against both Gram-positive and negative bacteria $B$. subtilis, E. coli and S. aureus, which suggest that the species could be a potential source for the extraction of such bioactive molecules.
In another study, in-vivo screening of chloroform extracts of A. faecalis isolated from Sponge Haliclona spp. inhibited the growth of Vibrio alginolyticus in Caenorhabditis elegans (Durai et al., 2013). However, in both the cases, extracted substances obtained either with ethyl acetate as in the present case or with chloroform, the active compound possessed by the bacterium in the form of metabolites found to be a potential source against many human pathogens. The findings suggest that both the active strains isolated from $L$. herbacea are capable of producing bioactive compounds against human pathogens. Also, L. herbacea happens to be a potential species contributing toward secondary metabolites like polybrominated diphenyl ethers (Unson et al., 1994), having several bioactive implications and it may be a major source from the Andaman Sea too towards the development of new drug molecules. Simultaneously, the possible role of two isolated bacteria $A$. faecalis and B. amyloliquefaciens from L. herbacea in the development of potential drugs cannot be overlooked.

\section{CONCLUSION}

Two identified symbionts $B$. amyloliquefaciens CAB1 and $A$. faecalis CAB38 isolated from $L$. herbacea exhibited activity against five bacterial pathogens. Both the species showed thermostability, i.e., B. amyloliquefaciens at a temperature 
of $60^{\circ} \mathrm{C}$ and salt tolerance at $8 \% \mathrm{NaCl}$, whereas $A$. faecalis has thermostability at $40^{\circ} \mathrm{C}$ and salt tolerance at $8 \%$ and $10 \%$ $\mathrm{NaCl}$. The antagonistic activity exhibited by these two isolates is attributed to the active metabolites produced by them. It can also be concluded from the present study that the endosymbiotic bacterial metabolites could be used as biocontrols.

\section{ACKNOWLEDGMENTS}

Authors would like to thank the Vice-Chancellor of Pondicherry University for providing logistic support to carry out the work. The financial support to Sneha Sawhney by University fellowship is duly acknowledged.

\section{REFERENCES}

Adhavan D, Mishra JK. Antibacterial property of secondary metabolites from symbiotic bacteria associated with marine sponge. J Coast Environ, 2012; 3(2):141-52.

Akond MA, Jahan MN, Sultana N, Rahman F. Effect of temperature, $\mathrm{pH}$ and $\mathrm{NaCl}$ on the isolates of actinomycetes from straw and compost samples from Savar, Dhaka, Bangladesh. Amer J Microbiol Immunol, 2016; 1(2):10-5.

Anand TP, Bhat AW, Shouche YS, RoyU, Siddharth J, Sarma SP. Antimicrobial activity of marine bacteria associated with sponges from the waters off the coast of South-East India. Microbiol Res, 2006; 161(3):252-62.

Belarbi EH, Go'mez AC, Chisti Y, Camacho FG, Grima EM. Producing drugs from marine sponges. Biotechnol Adv, 2003; 21(7):585-98.

Bhatnagar I, Kim S-K. Immense essence of excellence: marine microbial bioactive compounds. Mar Drugs, 2010; 8(10):2673-701.

Devi P, Revathi K. Anticancer activity of marine sponge Plakobranchus ocellatus extract on hepatocellular carcinoma cell line (Hep G2) and human breast cancer cell line (MCF-7). Int J Curr Res Med Sci, 2015; 1(6):30-4.

Dhasayan A, Selvin J, Kiran S. Biosurfactant production from marine bacteria associated with sponge Callyspongia diffusa. Biotechnol, 2015; 5(4):443-52.

Dhinakaran DI, Sivakumar T, Lipton AP. Detection of marine derived natural products synthesized in marine sponges collected from Tuticorin, India. Eur J Biol Sci, 2014; 6(1):01-6.

Durai S, Vigneshwari L, Balamurugan K. Caenorhabditis elegans-based in-vivo screening of bioactives from marine spongeassociated bacteria against Vibrio alginolyticus. J Appl Microbiol, 2013; 115:1329-42.

Flemer B, Kennedy J, Margassery LM, Morrissey JP, O'Gara F, Dobson AD. Diversity and antimicrobial activities of microbes from two Irish marine sponges, Suberites carnosus and Leucosolenia sp. J Appl Microbiol, 2011; 112(2):289-301.

Gopi M, Kumaran S, Kumar TT, Deivasigamani B, Alagappan K, Prasad SG. Antibacterial potential of sponge endosymbiont marine Enterobacter sp. at Kavaratti Island, Lakshadweep archipelago. Asian Pac J Trop Med, 2012; 5(2):142-6.

Handayani D, Sandrawaty N, Murniati M, Regina R. Screening of endophytic bacteria isolated from marine sponge Haliclona fascigera for inhibition against clinical isolates of methicillin resistant Staphylococcus aureus (MRSA). J Appl Pharm Sci, 2015; 5(09):139-42.

Hentschel U, Schmid M, Wagner M, Fieseler L, Gernert C, Hacker J. Isolation and phylogenetic analysis of bacteria with antimicrobial activities from the Mediterranean sponges Aplysina aerophoba and Aplysina cavernicola. FEMS Microbiol Ecol, 2001; 35(3):305-12.

Hildebrand M, Waggoner LE, Lim-Fong G, Sharp KH, Ridley CP, Haygood MG. Approaches to identify, clone and express symbiont bioactive metabolite genes. Nat Prod Rep, 2004; 21(1):122-42.

Hooper JNA, Soest RWM. Systema Porifera: a guide to the classification of sponges. Kluwer Academic Publishers/Plenum Publishers,
New York; Boston; Dordrecht; London; Moscow; Vol. 2, p. 1708, 2002

Hu GP, Yuan J, Sun L, She ZG, Wu JH, Lan XJ, Zhu X, Lin YC, Chen SP. Statistical research on marine natural products based on data obtained between 1985 and 2008. Mar Drugs, 2011; 9(4):514-25.

Immanuel T, Krishnan P, Raghunathan C. An updated report on the diversity of marine sponges of the Andaman and Nicobar Islands. In: Venkataraman K, Sivaperuman C (eds.). Marine faunal diversity in India. Elsevier (Acad. Press), UK, pp. 3-13, 2015.

Indraningrat AAG, Smidt H, Sipkema D. Bioprospecting sponge-associated microbes for antimicrobial compounds. Mar Drugs, 2016; 14(5):87.

Kiruba-Sankar R, Chadha NK, Dam-Roy S, Sawant PB, Saharan N, Krishnan P. Marine sponges as biological indicators of Oligotrophic Andaman Waters. IJMS, 2016; 45(2):338-41.

Kobayashi J, Ishibashi M. Bioactive metabolites of symbiotic marine microorganisms. Chem Rev, 1993; 93(5):1753-69.

Krishnan P, Veeramani S, Damroy S, Sarma K, Pavel K, Sunder J. Antimicrobial activity of Ircinia $s p$; a marine sponge and its associated bacteria from Andaman coast. Adv Anim Vet Sci, 2014; 2(1):37-41.

Kumar PS, Krishna ER, Sujatha P, Kumari BV. Screening and isolation of associated bioactive microorganisms from Fasciospongia cavernosa from of Visakhapatnam Coast, Bay of Bengal. J Chem, 2012; 9(4):2166-76

Lee YK, Lee J-H, Lee HK. Microbial symbiosis in marine sponges. J Microbiol, 2001; 39(4):254-64.

Lertcanawanichakul M, Sawangnop S. A comparison of two methods used for measuring the antagonistic activity of Bacillus species. Walailak J Sci Technol, 2008; 5(2):161-71.

Li ZY, Hu Y, Huang YQ, Huang Y. Isolation and phylogenetic analysis of the biologically active bacteria associated with three South China Sea sponges. Microbiol, 2007; 76(4):494-99.

Li ZY, Peng C, Shen Y, Miao X, Zang H, Lin H. L,LDiketopiperazines from Alcaligenes faecalis A72 associated with South China Sea sponge Stelletta tenuis. Biochem Syst Ecol, 2008; 36(3):230-4.

Maldonado M, Cortadellas N, Trillas MI, Rützler K. Endosymbiotic yeast maternally transmitted in a marine sponge. Biol Bull, 2005; 209(2):94-106.

Mehbub MF, Lei J, Franco C, Zhang W. Marine sponge derived natural products between 2001 and 2010: trends and opportunities for discovery of bioactives. Mar Drugs, 2014; 12(8):4539-77.

Mendpara J, Parekh V, Vaghela S, Makasana A, Kunjadia PD, Sanghvi G, Vaishnav D, Dave GS. Isolation and characterization of high salt tolerant bacteria from agricultural soil. Eur J Exp Biol, 2013; 3(6):351-8.

Muthiyan R, Nambikkairaj B, Mahanta N, Immanuel T, Mandal RS, Kumaran K, Kumar DA. Antiproliferative and proapoptotic activities of marine sponge Hyrtios erectus extract on breast carcinoma cell line (MCF7). Pharmacogn Mag, 2017; 13(1):S41-7.

Newman DJ, Hill RT. New drugs from marine microbes: the tide is turning. J Ind Microbiol Biotechnol, 2006; 33(7):539-44.

Pawlik JR, McFall G, Zea S. Does the odor from sponges of the genus Ircinia protect them from fish predators? J Chem Ecol, 2002; 28(6):1103-15.

Penesyan A, Tebben J, Lee M, Thomas T, Kjelleberg S, Harder $\mathrm{T}$, Egan S. Identification of the antibacterial compound produced by the marine epiphytic bacterium Pseudovibrio sp. D323 and related spongeassociated bacteria. Mar Drugs, 2011; 9(8):1391-402.

Pereira P, Raghunathan C, Mandol T, Chandra K. Marine sponges of India. In: Chandra K, Raghunathana C, Mondal T, Dash S (eds.). Current status of marine faunal diversity in India. Director ZSI. (Publ.), Kolkata, pp 106-24, 2016.

Proksch P, Edrada RA, Ebel R. Drugs from the seas: current status and microbiological imblications. Appl Microbiol Biotechnol, 2002; 59(2-3):125-34.

Radhakrishnan M, Vijayalakshmi G, Gopikrishnan V, Jerrine J. Bioactive potential of actinobacteria isolated from certain under-studied regions in India. J Appl Pharm Sci, 2016; 6(08):151-5. 
Ridley CP, Faulkner DJ, Haygood MG. Investigation of Oscillatoria spongeliae dominated bacterial communities in four dictyoceratid sponges. Appl Environ Microbiol, 2005; 71(11):7366-75.

Sawhney S, Mishra JK, Banu VS. Antibacterial activity of Bacillus velezensis $\mathrm{CHB} 2$, an endosymbiont of marine sponge Biemna fortis (Topsent, 1897) from South Andaman coast, India. Int J Basic Appl Res, 2018; 8(9):1012-23.

Schmidt EW, Obraztsova AY, Davidson SK, Faulkner DJ, Haygood MG. Identification of the antifungal peptide-containing symbiont of the marine sponge Theonella swinhoei as a novel delta-proteobacterium, 'Candidatus Entotheonella palauensis'. Mar Biol, 2000; 136(6):969-77.

Silambarasan S, Kumar EP, Murugan T, Saravanan D, Balagurunathan R. Antibacterial and antifungal activities of Actinobacteria isolated from Rathnagiri hills. J Appl Pharm Sci, 2012; 2(10):099-103.

Tamura K, Stecher G, Peterson D, Filipski A, Kumar S. MEGA6: molecular evolutionary genetics analysis version 6.0. Mol Biol Evol, 2013; 30:2725-9.

Taylor MW, Radax R, Steger D, Wagner M. Sponge-associated microorganisms: evolution, ecology and biotechnological potential. Microbiol Mol Biol Rev, 2007; 71(2):295-347.

Thacker RW, Freeman CJ. Sponge-microbe symbioses. Recent advances and new directions. Adv Mar Biol, 2012; 62:57-111.

Thomas TRA, Kavlekar DP, LokaBharathi PA. Marine drugs from sponge-microbe association - a review. Mar Drugs, 2010; 8(4):1417-68.

Unson MD, Holland ND, Faulkner DJ. A brominated secondary metabolite synthesized by the cyanobacterial symbiont of a marine sponge and accumulation of the crystalline metabolite in the sponge tissue. Mar Biol, 1994; 119(1):1-11.
Verma JP, Jaiswal DK, Krishna R, Prakash S, Yadav J, Singh $\mathrm{V}$. Characterization and screening of thermophilic Bacillus strains for developing plant growth promoting consortium from hot spring of Leh and Ladakh Region of India. Front Microbiol, 2018; 9:1293; doi:10.3389/ fmicb.2018.01293.

Webster NS, Taylor MW. Marine sponges and their microbial symbionts: love and other relationships. Environ Microbiol, 2012; 14(2):335-46.

Zahir I, Houari A, Bahafid W, Iraqui M, Ibnsouda S. A novel Alcaligenes faecalis antibacterial-producing strain isolated from a Moroccan tannery waste. Afr J Microbiol Res, 2013; 7(47):5314-23.

Zeng Z, Zhao J, Ke C, Wang D. Antimicrobial activities of novel cultivable bacteria isolated from marine sponge Tedania anhelans. Chin J Oceanol Limnol, 2013; 31:581-90.

Zheng L, Yan X, Xu J, Chen H, Lin W. Hymeniacidon perleve, associated bioactive Pseudomonas sp. NJ-6-3-1. Appl Biochem Microbiol, 2005; 41(1):35-9.

\section{How to cite this article:}

Sawhney S, Mishra JK. Bioactive potential of bacterial endosymbionts isolated from Lamellodysidea herbacea, marine sponge from the coast of South Andaman, India, against human bacterial pathogens. J Appl Pharm Sci, 2019; 9(03):001-008 